\title{
An Experimental Study To Assess The Effectiveness Of Foot Reflexology on Reduction Of Psychological Symptoms Among Adult Patients With Cancer In Selected Hospitals of Kanyakumari District, Tamil Nadu.
}

\author{
*Mrs. P. Jega Juliet \& **Dr. Mrs. SanthiAppavu
}

\section{Abstract:}

Objectives-To find out the effectiveness of foot reflexology on psychological symptoms among patients with cancer. Method-Experimental research design with pre and post test control group design. Result-In the control group mean and standard deviation of psychological symptoms before foot reflexology ( $54.5 \pm 6.8,23.6 \pm 2.6)$ and in post test (54.2 \pm 6.7 , $23.5 \pm 2.6)$ and $z$ test value $(-0.345,-0.575)$.Conclusion-The mean and standard deviation of psychological symptom anxiety and depression of patient with cancer before foot reflexology was $(51.0 \pm 6.6,26.1 \pm 4.0)$ respectively and after foot reflexology was $(42.0 \pm 4.53,16.5 \pm 3.2)$ and $z$ test value -3.792, -3.928 in experimental group. While comparing the pre test score to post test score there was a reduction of score in post test so it was very highly significant $(P<0.001)$.

Keywords: Foot Reflexology, Psychological Symptoms.

\section{INTRODUCTION}

Cancer as a single word incorporates a vast diversity of disease since there are as many tumor types as there are cell types in the human body. Therefore cancer is not a single disease, but a group of heterogenous diseases that share common biological properties. The cancer research revolution has also demonstrated that all cancers are genetic and share common molecular pathogenesis. All cancers are the result of mutations in oncogenes and tumor suppressor genes. Each specific cancer occurs through mutation in specific genes. ${ }^{1,2}$

Cancer is the second leading cause of death globally and was responsible for 8.8 million deaths in 2015. Globally, nearly in 1 in 6 death is due to cancer. Approximately $70 \%$ of deaths from cancer occur in low and middle income countries. Around one third of deaths from cancer are due to the 5 leading behavioral and dietary risk, high body mass index, low fruit and vegetable intake, lack of physical activity, tobacco use and alcohol use. ${ }^{3}$

The psychological symptoms of patients with cancer are anxiety and depression. These feelings are normal since cancer is an obvious threat to the person's wellbeing. However,

many myths and assumptions exists which suggest that all patients with cancer must be depressed and require psychiatric intervention. 4

Reflexology is the application of appropriate pressure to specific points and areas on the feet, hands. Reflexologist believe that these areas and reflex points correspond to 
different body organs and systems and that passing them has a beneficial effect on the organs and person's general health. ${ }^{5}$

\section{Statement of the problem:}

An experimental study to assess the effectiveness of foot reflexology on reduction of psychological symptoms among adult patients with cancer in selected hospitals of Kanyakumari District, Tamil Nadu.

\section{Objectives:}

1. To assess the level of psychological symptoms among patients with cancer in experimental and control group before foot reflexology.

2. To find out the effectiveness of foot reflexology on psychological symptoms among patients with cancer.

3. To find out the association between the level of psychological symptoms and their selected demographic variables.

\section{Hypotheses:}

H1: There is a significant difference between the level of psychological symptoms among the patients with cancer before and after implementation of foot reflexology

$\mathrm{H} 2$ : There is a significant association between the level of psychological symptoms among patients with cancer, and their selected demographic variables.

\section{Research Methodology}

\section{METHODOLOGY:}

Experimental with Onegroup pretest - post-test design was adopted for the study. The study was conducted in the patients with cancer in International Cancer Centre, Neyyoor. A total of 40 adult patients with cancer, 20 in experimental group and 20 in control group were selected by simple random sampling technique and data were selected by using questionnaire method. The questionnaire consists of 30 multiple choice questions related to knowledge

\section{Sampling criteria Inclusion:}

- Patient with cancer in the age group of 25 - 55 years

- Patient with cancer admitted in International Cancer Centre for a period of minimum 10 days.

\section{Exclusion:}

- Patient with cancer with critical illness

- Patient with cancer who are severely debilitated.

\section{Setting of the study:}

The study was conducted in International Cancer Centre, Neyyoor.

\section{Tool Construction:}

The tool consisted of three sections

Section I: Demographic data

Section II: Modified state trait Anxiety scale Section III: Modified Major depression inventory

\section{Data collection procedure:}

After self introduction and study detail 40 subjects were selected through random sampling technique. Pretest was conducted on the first day of contract followed by 10 days foot reflexology was given by the investigator for 15 minutes for each foot. At the 10 day post test was conducted.

\section{Result:}

The data were analyzed using descriptive and inferential statistics. The findings of the study were in experimental group majority of the patient with cancer belongs to the age group of 35 - 44 years (50\%), were male (70\%), Christian (55\%), Married (90\%), High school educated (35\%), Labourers (45\%), were from nuclear family (50\%), and having the hobbies of watching TV (75\%)

In control group most of them (45\%), belongs to the age group of $35-44$ years, were male $(70 \%)$, Christian $(60 \%)$, were married (95\%), High school education (45\%), were labourers (45\%), belongs to nuclear family $(70 \%)$, and having the hobbies of chatting with friends $(50 \%)$ 


\section{Effectiveness of foot reflexology in Experimental Group}

\begin{tabular}{|c|c|c|c|c|c|c|c|c|c|c|c|c|}
\hline \multirow{3}{*}{$\begin{array}{c}\text { Psycho- } \\
\text { logical } \\
\text { Symptoms }\end{array}$} & \multicolumn{4}{|c|}{$\begin{array}{c}\text { Experimental Group } \\
(n=20)\end{array}$} & \multirow{3}{*}{$\begin{array}{c}Z \\
\text { Test }\end{array}$} & \multirow{3}{*}{ Sig } & \multicolumn{4}{|c|}{ Control group $(n=20)$} & \multirow{3}{*}{$Z$ Test } & \multirow{3}{*}{$i g$} \\
\hline & \multicolumn{2}{|c|}{ Pre test } & \multicolumn{2}{|c|}{ Post Test } & & & \multicolumn{2}{|c|}{ Pre test } & \multicolumn{2}{|c|}{ Post Test } & & \\
\hline & Mean & $S D$ & Mean & $S D$ & & & Mean & $S D$ & Mean & $S D$ & & \\
\hline Depression & 26.1 & 4 & 16.5 & 3.2 & 3.928 & $P<0.001$ & 23.6 & 2.6 & 23.5 & 2.6 & -0.345 & $P>0.05$ \\
\hline Anxiety & 51.0 & 6.6 & 42.0 & 4.5 & $\begin{array}{c}- \\
3.792\end{array}$ & $P<0.001$ & 54.5 & 6.8 & 54.2 & 6.7 & -0.575 & $P>0.05$ \\
\hline
\end{tabular}

The above table showed that the mean and standard deviation of psychological symptom anxiety and depression of patient with cancer before foot reflexology was $(51.0 \pm 6.6,26.1 \pm 4.0)$ respectively and after foot reflexology was $(42.0 \pm 4.53,16.5 \pm 3.2)$ and $\mathrm{z}$ test value $3.792,-3.928$ in experimental group. While comparing the pre test score to post test score there was a reduction of score in post test so it was very highly significant $(\mathrm{P}<0.001)$. Hence the intervention foot reflexology is effective in reducing psychological symptoms (anxiety, depression).

In the control group mean and standard deviation of psychological symptoms before foot reflexology (54.5 \pm 6.8, 23.6 \pm 2.6$)$ and in post test (54.2 \pm 6.7 , $23.5 \pm 2.6)$ and $\mathrm{z}$ test value $(-0.345$, $0.575)$. While comparing pre test to post test score. There is no reduction of post test score. Hence there was no statistical significant association at $(\mathrm{P}>0.05)$ levels.

\section{Conclusion:}

The present study revealed that, the intervention foot reflexology is very effective in reducing psychological symptoms (anxiety, depression) among patients with cancer. When compared to the control group.

\section{References:}

1. Holland JF, Cardinal Manifestations of Cancer. I Kufe DW, Pollock RE, Weichselbaum RR et al, editors: Holland Frei Cancer Medicine 6, Hamilton Oatario, 2003, BC Decker.

2. Kinzler KW, Vogelstein 13: Introduction. In Vogelstein B, Kinsler KW, editors: The genetic basis of human cancer, ed 2, Newyork, 2002, McGraw Hill.

3. WHO, Feb 2017

4. Massie Mt, Chertkor C Roth AJ: Psychological issues. In Devita $\mathrm{V}$, Hellman S, Rosenberg S, Principle and practive of oncology. $5^{\text {th }}$ edition; Philadelphia; Lippincott William Wilking; 1997.

5. Karen teagarden (2004). A book on reflexology 2nd ed. Pennsylvania: spring house, P: 348-12. 